Boston University School of Law

Scholarly Commons at Boston University School of Law

Faculty Scholarship

2006

Congress, Controlled Substances, and Physician-Assisted Suicide:

Elephants in Mouseholes

George J. Annas

Follow this and additional works at: https://scholarship.law.bu.edu/faculty_scholarship

Part of the Health Law and Policy Commons 


\title{
Congress, Controlled Substances, and Physician-Assisted Suicide - Elephants in Mouseholes
}

\author{
George J. Annas, J.D., M.P.H.
}

The U.S. Supreme Court's decision in Gonzales v. Oregon to reject the U.S. attorney general's authority to prohibit physicians in Oregon from prescribing Schedule II drugs for their terminally ill patients to commit suicide can seem paradoxical and confusing. ${ }^{1}$ How is it that California cannot permit the patients of physicians who recommend marijuana, a Schedule I drug, to possess legally and use marijuana that they may need to survive, but Oregon can legally permit physicians to prescribe Schedule II drugs and patients to possess and use such drugs to end their lives?

The key to the answer lies in distinguishing between the two classes of questions by which the U.S. Supreme Court primarily decides cases: is a statute consistent with the U.S. Constitution - that is, is it "constitutional"? - and what does a federal statute actually mean? The California case was decided on the basis of the first question, and the Oregon case on the second. More specifically, in the California case, Congress had outlawed any use of marijuana by classifying it under Schedule I, which includes drugs that have "no currently acceptable medical use." The legal question was whether Congress had the constitutional authority to make this classification under its Commerce Clause powers. ${ }^{2}$ The Court determined that it did, concluding that the Commerce Clause gave Congress the same power to regulate marijuana grown at home for personal, medically related uses as it had to regulate the amount of wheat a farmer grew on his farm for personal consumption. ${ }^{3}$ The fact that a physician would recommend or prescribe the marijuana for medical purposes was found to be irrelevant. ${ }^{2,3}$ In the Oregon case, the power of Congress to regulate the use of drugs in the practice of medicine is not at issue; Congress can set national drug-prescribing rules. The question is: how did Congress affect the authority of states to set medical practice standards by enacting the Controlled Substances Act in 1970, which places substances in one of five schedules on the basis of their potential for abuse or dependence?

THE CONTROLLED SUBSTANCES ACT

Justice Anthony Kennedy wrote the opinion of the Court in Gonzales v. Oregon, which was decided by a six-to-three vote. The opinion begins: "The question before us is whether the Controlled Substances Act (CSA) allows the United States Attorney General to prohibit doctors from prescribing regulated drugs for use in physicianassisted suicide, notwithstanding a state law permitting the procedure." ${ }^{1}$ In 1997 the Court had observed that "Americans are engaged in an earnest and profound debate about the morality, legality, and practicality of physician-assisted suicide." 4 The current case is not about the Oregon law itself but about whether Congress had given the U.S. attorney general the authority to nullify its effect.

The Oregon statute - the first and still the only state law to authorize physicians to write prescriptions for a lethal dose of drugs for patients who were terminally ill but mentally competent and who asked for such a prescription at least twice - was adopted by ballot measure, first in 1994 and again in 1997. ${ }^{\text {In 1997, Attor- }}$ ney General Janet Reno was asked by a group of senators to determine that prescribing drugs for suicide was not a "legitimate medical practice," as required by the Controlled Substances Act, and that writing such a prescription could therefore result in the revocation of one's registration certificate with the Drug Enforcement Administration (DEA) and federal criminal prosecution. Reno refused, concluding that the Controlled Substances Act did not authorize her to "displace the states as the primary regulators of the medical profession, or to override a state's determination as to what constitutes legitimate medical practice." ${ }^{11}$

John Ashcroft, who as a senator had support- 
ed federal efforts to curtail physician-assisted suicide, was appointed attorney general in 2001. In November 2001 he issued an Interpretive Rule that stated:

[A]ssisting suicide is not a "legitimate medical purpose" within the meaning of [existing regulations], and prescribing, dispensing, or administering federally controlled substances to assist suicide violates the Controlled Substances Act. Such conduct by a physician registered to dispense controlled substances may "render his registration . . . inconsistent with the public interest" and [is] therefore subject to possible suspension or revocation . . . regardless of whether state law authorizes or permits such conduct by practitioners or others and regardless of the condition of the person whose suicide is assisted. ${ }^{6}$

Every prescription filled under the Oregon law has included Schedule II drugs, and such drugs cannot be legally prescribed without registration with the Drug Enforcement Administration. Thus, in practice, the Oregon law would be rendered ineffective by the Ashcroft rule. Accordingly, a lawsuit was filed in the U.S. District Court of Oregon, and the court enjoined the enforcement of the rule. ${ }^{7}$ The Court of Appeals for the Ninth Circuit affirmed the decision, holding that the Ashcroft rule was invalid because, by making a medical procedure authorized under Oregon law a federal offense, the rule changed "the usual constitutional balance between the States and the Federal Government" without a clear congressional statement authorizing this change. ${ }^{8}$

STATUTORY INTERPRETATION

As a general rule, courts permit officials in the executive branch who are charged with administering specific statutes, such as the Controlled Substances Act, to interpret their meaning. Courts give "substantial deference" to these interpretations if the statute is ambiguous and Congress has given the agency the authority to make regulations to enforce it.

How much deference did Attorney General Ashcroft's interpretation of the Controlled Substances Act deserve? The Court decided it didn't deserve much, for three basic reasons. First, the
Court found as unpersuasive the government's argument that the attorney general was really just interpreting one of his own regulations, since the regulation did "little more than restate the terms of the statute itself," and thus the attorney general was actually interpreting the statute itself, not one of his own regulations. Specifically, the Controlled Substances Act requires that controlled substances be prescribed only for a "currently accepted medical use" and that a "valid prescription" can only be "issued for a legitimate medical purpose." The regulation uses terms that are substantially identical, and the Court concluded that by simply restating a statute, like a parrot, an agency gets no "special authority to interpret its own words." ${ }^{1}$

The second reason the Court gave for not granting deference to the attorney general's interpretation is that the Controlled Substances Act is not ambiguous and Congress did not delegate the authority to the attorney general to interpret the act. One reason is that if the attorney general really had the power to remove physicians from the Controlled Substances Act registry simply because he concluded that their registrations were inconsistent with "the public interest," the attorney general's power would be "extraordinary." He would, for example, have been given the power "to deregister a physician simply because he deemed a controversial practice permitted by state law to have an illegitimate medical purpose" - not just the statutory power to remove the registrations of physicians who falsified their applications, were convicted of a felony, or had their state medical licenses revoked. But, the Court concluded, nothing in the Controlled Substances Act gives the attorney general the power to "define the substantive standards of medical practice. ..." Instead, the Court noted, it is the secretary of Health and Human Services who has authority under the Controlled Substances Act to set medical standards, specifically those involving "the medical treatment of . . . narcotic addiction."

To support this conclusion, the Court referred directly to an international treaty, the Convention on Psychotropic Substances, which the United States had ratified. When it passed a statute to enforce the convention, Congress specifically stated that "nothing in the Convention will interfere with the ethical practice of medicine as determined by [the secretary of Health and Human Services] on the basis of a consen- 
sus of the view of the American medical and scientific community." The Court found that the structure of the Controlled Substances Act is the same as the structure of its law enforcing the Convention and thus conveys an unwillingness on the part of Congress "to cede medical judgments to an Executive official who lacks medical expertise." Congress has the constitutional power to delegate medical decision-making authority to the attorney general. But the Court found that Congress did not do so because, among other reasons, the judgments the attorney general claimed to have the legal authority to make are "quintessentially medical judgments," "beyond his expertise and incongruous with the statutory purposes and design." ${ }^{1}$ Citing one of its prior cases, the Court has adopted its central metaphor to decide this case: "Congress, we have held, does not alter the fundamental details of a regulatory scheme in vague terms or ancillary provisions - it does not, one might say, hide elephants in mouseholes."1

A LEGITIMATE MEDICAL PRACTICE?

The final argument that the Court considered was the attorney general's claim that the Controlled Substances Act itself prohibits physicianassisted suicide with the use of controlled substances because this use of Schedule II drugs is not a "legitimate medical practice." In the California medical marijuana case, the Court concluded that in enacting the Controlled Substances Act, Congress sought to "conquer drug abuse and to control the legitimate and illegitimate traffic in controlled substances." The Court had not previously had occasion, however, to determine "the extent to which the CSA regulates medical practice beyond prohibiting a doctor from acting as a drug 'pusher' instead of a physician." The Court had previously decided that the law prohibits the "large-scale overprescribing of methadone," which is not consistent with accepted medical practices, ${ }^{9}$ and in the California case that Congress itself had expressly found that marijuana had no accepted medical use. ${ }^{2}$

The Court ruled that, on the basis of its "text and design," the Controlled Substances Act cannot reasonably be read as prohibiting physicianassisted suicide. The Court reached this conclusion because "the statute manifests no intent to regulate the practice of medicine generally" and because, under basic principles of federalism, the states have "great latitude under their police powers to legislate as to the protection of the lives, limbs, health, comfort, and quiet of all persons." ${ }^{1}$ The Court concluded not only that the practice of medicine is a state-regulated activity and that Congress did not mean to make it federally regulated under the Controlled Substances Act, but also that the Oregon law itself is a good example of how states actually regulate the practice of medicine:

Rather than simply decriminalizing assisted suicide, [the Oregon law] limits its exercise to the attending physicians of terminally ill patients, physicians who must be licensed by Oregon's Board of Medical examiners. . . . The statute gives attending physicians a central role, requiring them to provide prognoses and prescriptions, give information about palliative alternatives and counseling, and ensure patients are competent and acting voluntarily. Any eligible patient must also get a second opinion from another registered physician, and the statute's safeguards require physicians to keep and submit to inspection detailed records of their actions. ${ }^{1}$

Nonetheless, the Court found as "at least reasonable" the attorney general's contention that physician-assisted suicide is not a legitimate medical practice because it violates the position of prominent medical organizations, the federal government, and 49 states. ${ }^{1}$ A "reasonable" interpretation of a statute on the part of the attorney general would be acceptable to the Court, but only if the statute itself authorized the attorney general to interpret it. The Court decided that the Controlled Substances Act did not allow this interpretation, because Congress did not authorize the attorney general "to bar a use [of a controlled substance] simply because it may be inconsistent with one reasonable understanding of medical practice." Instead, the Court concluded that the attorney general's powers under the Controlled Substances Act consist only of restricting the prescribing practices of physicians of drugs that have a potential for addiction or recreational use. To "read prescriptions for assisted suicide as constituting 'drug abuse' under the CSA is discordant with the phrase's consis- 
tent use throughout the statute, not to mention its ordinary meaning." 1 The Court ended the opinion with a characterization of its ruling as a "commonsense" one in that "the background principles of our federal system . . . belie the notion that Congress would use such an obscure grant of authority to regulate areas traditionally supervised by the States' police powers."

States have traditionally licensed physicians and regulated the practice of medicine. Federal activity historically has been limited to regulating the manufacture and sale of drugs and devices and to controlling drug trafficking and recreational uses of drugs. Once a drug is approved as "safe and effective" for any use, physicians are able to exercise their medical judgment to prescribe it for any other use consistent with the practice of medicine, as determined by state law and actual medical practice. Ultimately, the Court ruled, nothing Congress did when it enacted the Controlled Substances Act changed the respective roles of the states and the federal government.

JUSTICE SCALIA'S DISSENT

Justice Antonin Scalia wrote a dissent, which was joined by Justice Clarence Thomas and Chief Justice John Roberts. Scalia would have deferred to the attorney general's interpretation of the Controlled Substances Act. Scalia's strongest argument, I think, is that Congress had set an objective federal standard of "legitimate medical practice" when it enacted the Controlled Substances Act. Under this federal standard, it was (as the majority of the Court conceded) "at least reasonable" (a phrase Scalia described as testing "the limits of understatement") for the attorney general to conclude, on the basis of the laws of 49 states and the federal government as well as basic standards of medical ethics, that assisting a patient's suicide is not a legitimate medical purpose of a drug prescription. Scalia argued that the majority had confused "the normative inquiry of what the boundaries of medicine should be which it is laudably hesitant to undertake - with the objective inquiry of what the accepted definition of 'medicine' is." Scalia continued, "The fact that many in Oregon believe that the boundaries of 'legitimate medicine' should be extended to include assisted suicide does not change the fact that the overwhelming weight of authority . . . confirms that they have not yet been so extended."
Scalia also rejected the notion that hiding "elephants in mouseholes" was an apt description of congressional intent, noting that the attorney general has attempted to regulate the uses of controlled substances outside the setting of addiction and recreational use in only four areas: assisted suicide, aggressive therapy of pain management, the use of anabolic steroids, and cosmetic weightloss therapy. In none of these four areas, Scalia argued, had the attorney general's assertion of power done anything to undermine the statutory scheme.

Scalia found that all of the attorney general's actions were consistent with a reasonable interpretation of a "uniform federal standard for legitimacy of medical practice" in relation to the prescription of drugs. Scalia closed his opinion with an agreement with the majority that Congress can outlaw physician assisted-suicide if it wants to:

Using the federal commerce power to prevent assisted suicide is unquestionably permissible. The question before us is not whether Congress can do this, or even whether Congress should do this; but simply whether Congress has done this in the CSA. I think there is no doubt that it has. ${ }^{1}$

THE ROLE OF PHYSICIANS

Like most judicial opinions devoted to the interpretation of a statute, this one is not all that monumental, and Congress can rewrite the statute if it disagrees with the Court's interpretation. Although the vote was six to three, the outcome of the case was difficult to predict in advance. I have never been all that enamored of the Oregon law, and I continue to believe that Oregon's approach of providing physicians with immunity for the prescription of drugs for suicide is flawed - both because it undercuts medical professionalism by making the prescription of drugs for terminally ill patients who might be suicidal "much more bureaucratic and burdensome, and less private and accountable" and because it requires physicians specifically "to intend the deaths of their patients." 10 Nonetheless, more than a decade after its enactment, in a contest between the seldom-used Oregon statute and a federal agency's assertion of power over all U.S. physicians' pre- 
scriptions of scheduled drugs, it was not really possible to root for the attorney general. Moreover, the DEA lately has seemed much more menacing to physicians than it had been, especially since the agency withdrew its support for painprescribing guidelines that had been adopted by the Federation of State Medical Boards. ${ }^{11,12}$ Quill and Meier, for example, have argued that, had the Court ruled the other way, "physicians may become hesitant to prescribe the best available medications to manage the pain, agitation, and shortness of breath that sometimes accompany the end stages of illness. As a result, they may, in essence, abandon patients and their families in their moment of greatest need."13

To the extent that this prophecy might have been correct, Gonzales v. Oregon should be a major comfort to physicians, for two reasons. First, the majority of the justices found great significance in the fact that the Oregon statute sets procedures for physicians to follow and explicitly trusts that they will follow them in the exercise of medical judgment. Thus, the Court's characterization, in the California medical marijuana case, of some physicians as potential criminals now seems limited to physicians involved in drug trafficking of the type included in the Controlled Substances Act. Second, this opinion strictly limits the jurisdiction of the DEA with regard to physicians to those involved in drug trafficking. Physicians who treat terminally ill patients or patients with cancer at any stage of their illness have never had much to fear from the DEA; now they have nothing to fear from it. As Quill and Meier might put it, to the extent that "for better or worse, the DEA sets the tone and drives perceptions about legal risk associated with prescribing Schedule 2 drugs for seriously ill and dying patients,"13 the tone should be nothing but supportive of keeping patients free of pain and discomfort.

Virtually anything that encourages what has been termed "a palliative ethic of care"14 has strong public support and is supported by the Court as well. This attitude is probably why, although all nine justices agree that Congress has the constitutional authority under the Commerce Clause to outlaw the prescription of controlled substances for physician-assisted suicide at any time, there has been no movement in Congress to do so. The lack of Congressional reaction to the opinion may also reflect the overwhelming condemnation on the part of the public of Congress's attempt to interfere with the medical (and legal) judgments about the treatment of Terri Schiavo. ${ }^{14-16}$

NATIONAL STANDARDS

OF MEDICAL PRACTICE

Now that there is no longer any serious question that Congress has the authority under the Commerce Clause to regulate the practice of medicine, the issue of national medical licensure and standards of medical practice may receive more attention. The Court is certainly correct in noting that Congress historically has been loath to legislate medical practice, preferring to see the areas in which it has legislated - such as drug trafficking, recreational drug use, female genital mutilation, and even so-called partial-birth abortion - not as the practice of medicine at all, but something outside of it. Nonetheless, there is tension between the historical role of the state in terms of licensing physicians and setting standards of medical practice and arguments in favor of national practice standards.

Medical schools are all substantially identical in their training, and all their graduates must pass the same national examinations. State licensure seems to be a relic in a country where actual practice standards are set nationally and where local variations of these standards are seen as problems. Furthermore, Congress has acted to attempt to control medical practices that it has viewed as intolerable. For example, it has acted in the areas of medical research standards, in order to protect human subjects, and emergency treatment requirements in hospitals, in order to protect patients with a medical emergency. The question is not whether national practice standards for physicians and hospitals could be a good thing; they could be. It has been persuasively suggested, for example, that the adoption of six patient-safety practices by U.S. hospitals could save up to 100,000 lives in the first two years. ${ }^{17}$ The question is, who will have the authority to set the practice standards? It is one thing to decide that national standards will be set by the relevant specialty boards or other national medical organizations on the basis of evidence that supports the relevance of such standards to the health and welfare of patients; it is quite another to say that standards will be set by Congress or the attor- 
ney general on the basis of the political winds of the day.

No potential conflict of interest relevant to this article was reported.

From the Department of Health Law, Bioethics, and Human Rights, Boston University School of Public Health, Boston.

1. Gonzales v. Oregon, 126 S.Ct. 904 (2006).

2. Gonzales v. Raich, 125 S.Ct. 2195 (2005).

3. Annas GJ. Jumping frogs, endangered toads, and California's medical-marijuana law. N Engl J Med 2005;353:2291-6.

4. Washington v. Glucksberg, 521 U.S. 702 (1997).

5. Oregon Death with Dignity Act, Ore. Rev. Stat. $\$ 127.800$ et seq. (2003).

6. Office of Attorney General. Dispensing of controlled substances to assist suicide. Fed Regist 2001;66:56607-8.

7. Oregon v. Ashcroft, 192 F.Supp. 2d 1077 (U.S. Dist. Ore. 2002).

8. Oregon v. Ashcroft, 368 F.3d 1118 (2004).

9. U.S. v. Moore, 423 U.S. 122 (1975).
10. Annas GJ. Death by prescription: the Oregon initiative. N Engl J Med 1994;331:1240-3.

11. The myth of the "chilling effect." News release of the Drug Enforcement Administration, Alexandria, Va., October 30, 2003. (Accessed February 17, 2006, at http://www.usdoj.gov/dea/pubs/ pressrel/pr103003.html.)

12. Johnson SH. The social, professional, and legal framework for the problem of pain management in emergency medicine. J Law Med Ethics 2005;33:741-60.

13. Quill TE, Meier DE. The big chill - inserting the DEA into end-of-life care. N Engl J Med 2006;354:1-3.

14. Fins JJ. A palliative ethics of care: clinical wisdom at life's end. Boston: Jones and Bartlett, 2005.

15. Blendon RJ, Benson JM, Herrmann MJ. The American public and the Terri Schiavo case. Arch Intern Med 2005;165:2580-4.

16. Annas GJ. "Culture of life" politics at the bedside: the case of Terri Schiavo. N Engl J Med 2005;352:1710-5.

17. Berwick DM, Calkins DR, McCannon CJ, Hackbarth AD. The 100,000 lives campaign: setting a goal and a deadline for improving health care quality. JAMA 2006;295:324-7.

Copyright (c) 2006 Massachusetts Medical Society.

CLINICAL TRIAL REGISTRATION

The Journal encourages investigators to register their clinical trials in a public trials registry. The members of the International Committee of Medical Journal Editors plan to consider clinical trials for publication only if they have been registered (see N Engl J Med 2004;351:1250-1).

The National Library of Medicine's www.clinicaltrials.gov is a free registry, open to all investigators, that meets the committee's requirements. 